\title{
Proposed site selection criteria for hazardous waste disposal facilities in Iraq
}

\author{
L. Al-Taie, N. Al-Ansari, R. Pusch \& S. Knutsson \\ Luleå University of Technology, Luleå, Sweden
}

\begin{abstract}
Hazardous wastes in Iraq can be considered as a looming crisis due to its severe impact on health and environment after the 1991 and 2003 wars. The most dangerous type is depleted uranium waste. It is classified by EU and USEPA as Low-Level radioactive Waste and a simple and sufficiently safe way of isolating it from the biosphere is to turn it into a landfill confined within tight dikes. Selection of a disposal site requires a number of conditions to be fulfilled, like socio/economic, environmental and geotechnical criteria, which, in combination, determine where such landfills can be located. This is particularly obvious for Iraq, with its large desertic areas that are available for constructing landfills of hazardous waste. The climatic conditions are suitable and the deep groundwater level valuable for minimizing or avoiding contamination of the area. Heavy rain may occasionally fall requiring special measures to be taken for maintaining stability and tightness. This paper lists suitable site selection criteria for landfills of hazardous waste with special respect to Iraq. An example of a suitable disposal site is described and assessed.

Keywords: hazardous waste, depleted uranium, Iraq, repository, landfill, site selection, Al-Jezira desert.
\end{abstract}

\section{Introduction}

Wars in Iraq (1991 and 2003) generated various types of hazardous waste, termed HW in this paper, the ones that we will consider here being soil contaminated by depleted uranium (DU) $[1,2]$. Other HW emanates from destroyed army vehicles and remnants of Iraqi nuclear facilities holding various types and amounts of chemical and radioactive material IAEA [3]. A report issued by the Iraqi Ministry of Environment [4] prepared in co-operation with 
IAEA revealed that the destroyed facilities were contaminated by soil causing radiation ranging from low to high levels [5]. The amount of contaminated soil and tools successively accumulated during the wars.

The impact on the health conditions of the population was reported from different parts of Iraq, showing a high frequency of cancer and abnormally born infants $[6,7]$. HW was defined as material being flammable, corrosive, reactive and toxic [8]. According to United States Nuclear Waste Policy Act, DU is classified as HW and can be categorized as LLW. This type of waste should be disposed so that the environment is protected and public health unaffected for a predetermined period of time. Near-surface repositories (NSR) represent the most common and least expensive way of isolating low-level and short-lived intermediate level radioactive wastes (LILW) $[9,10]$.

Internationally, the time frame of the containment of LILW is designated to be 300 years [11]. NSR is expected to perform effectively for at least this period of time because of its multibarrier function: a bottom liner system, a system for collecting and discharging leached fluid, and a tight top cover [12]. These components should be designed so that they are mutually compatible and combined to effectively isolate the waste. The site selection affects and largely controls the selection of a suitable design. The aim of both is to minimize or eliminate migration of hazardous chemical elements from the waste to the groundwater and shallow soil.

This paper defines site selection criteria, focusing on the environmental, geological and socio-economic factors. The application of these criteria is employed here to select a preliminary candidate site for disposing HWs.

\section{Successful examples of $\mathrm{HW}$ disposal facilities}

\subsection{Centre la Manche and centre de l'Aube NSR, France}

La Manche, the first disposal facility for radioactive waste in the world, was built in 1969 at Digulleville, east of La Hague's reprocessing plant for nuclear fuel. In 1994, la Manche was abandoned after 25 years' service, providing more than $500,000 \mathrm{~m}^{3}$ of LILW. The French government decided to establish a new facility at l'Aube in 1992, fifty kilometres east of Troyes, for taking care of forthcoming HWs. It covers 95 ha with 30 ha disposal area that can host $1,000,000 \mathrm{~m}^{3}$ of radioactive wastes, cf. fig. 1 . Until 2006, l'Aube received around $200,000 \mathrm{~m}^{3}$ of radioactive waste $[13,14]$.

\subsection{El Cabril repository, Spain}

The facility in Spain was designed to contain $100,000 \mathrm{~m}^{3}$ of LILW from Spanish nuclear and research activities. It is situated in the province of Cordoba at the foothills of Sierra Albarrana. Construction started in 1990 and the facility was officially announced to be ready for receiving wastes in 1992. The El Cabril NSR reached $54 \%$ of its disposing capacity in 2006 and it is still running safely and efficiently $[15,16]$. 


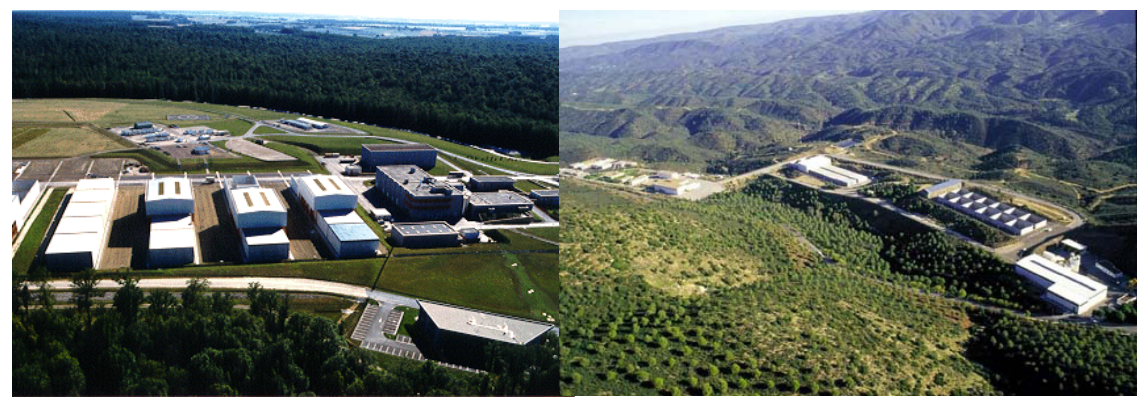

Figure 1: Right, El Cabril repository, Spain [19] and on the left, L'Aube disposal facility, France [20]. They were situated on an elevated area which provides excellent protection of groundwater and good drainage characteristics of the percolated water.

\subsection{Lithuanian NSR}

The main objective of this facility was to dispose LILW from the decommissioning of the Ignalina nuclear power plants by constructing a disposal facility on the ground as near as possible to the mentioned nuclear power plant. In 2003, the government of Lithuania initiated the site identification process which ended in November 2007 by recommending Stabatiške site among the nine candidate sites to be selected for constructing a NSR. It would require a 40 ha area including the disposal section of 10 ha, which was designed to take $100,000 \mathrm{~m}^{3}$ of radioactive waste. The construction of the facility was planned to be complete in 2016 [17, 18].

\subsection{Tentative conclusions}

The main principles applied in the aforementioned cases are preferably followed also in the siting process of Iraqi HW facilities. Thus, the selection of suitable sites should be based on the following criteria 1) stable geological formation, 2) low seismic activity, 3) simple hydrology (implying an elevated area for discharge of rain- and meltwater), 4) public acceptance 5) areas of low economic value and 6) low population density. The l'Aube and El Cabril disposal facilities have excellent topographical conditions by being located on elevated land. The latter, is however, vulnerable to seismic impact.

\section{Proposed site selection criteria of HW facilities}

They are discussed here on the basis of three perspectives.

\subsection{Environmental factors}

The selected site must fulfil basic requirements with respect to the role of the groundwater. A deep groundwater level is preferred and the groundwater 
composition must be compatible with the chemical performance of the waste disposal facilities and the waste. The flow direction of the groundwater away from downstream communities is preferable since it would cause minimal contamination of the ground in populated areas. Furthermore, selection of a site on the floodplain of major rivers (Tigris and Euphrates) requires location well over the level representing 100-year flooding. Positions very near a river or lake should be avoided and also wetlands and marshes [21, 22].

\subsection{Geological factors}

Sites on elevated areas will provide good hydrological conditions like a deep groundwater level and protection against flooding. The sub-soil properties also play a role because they determine the rate of flow of surface water and groundwater and the possibility of fixation of certain cationic contaminants. Thus, the hydraulic conductivity, cation exchange capacity and $\mathrm{pH}$ value will affect the efficiency of the containment of the waste. The seismic conditions of a candidate site must be considered and the impact of earthquakes on the performance of the selected design of the landfill be predicted. Moreover, areas sensitive to mass movements like large-scale slides due to gravitational forces and artesian conditions should be excluded. The existence of faults, especially active ones, may generate stability problems and should also be avoided. Karst phenomena in areas with soluble rocks (e.g. limestone and gypsum) can give great problems because of hidden cavities that can cause sudden and strong subsidence. Such areas should therefore be ruled out. Hyper-arid regions are normally subjected to sand dune movement that must be taken into consideration since they can affect the disposal facility by changing the topography [21-23].

\subsection{Socio-economic factors}

The availability of roads and railways to the disposal facility is of fundamental importance for construction of the landfill and for bringing contaminated soil and solids there. Electric power and fresh water are important facilities meaning that the distance to power transmission lines is a parameter to be considered and also the possibility to transport water and store it at the construction site. The nominated site should be located at least $500 \mathrm{~m}$ away from the nearest village or permanently populated area. A very important factor is the need for public acceptance, which effectively controls the entire selection process and requires professional hydrological and agricultural investigations with risk analysis to be made. It must hence be shown that the selected area will not adversely affect public health, quality of life, local land and property values. Moreover, the visual impact related to the disposal facility is another factor that may have a negative impact on the public opinion. Landscaping has to be made for adapting the landfill to the existing topography and terrain as much as possible and here is where wind-borne sand in desert areas needs special attention. Naturally, location of the landfills should preferably be in areas of low economic value with due respect also to protection of the national archaeological heritage and wildlife $[23,24]$. 


\section{Al-Jezira desert as a disposal site}

\subsection{Geological and metrological features}

Iraq has a total area of $438,317 \mathrm{~km}^{2}$ of which $60 \%$ is considered as desert. These areas are known as the Western, Southern and Al-Jazira deserts. The Al-Jazira desert covers an area of $29,270 \mathrm{~km}^{2}$, which represent about $6.7 \%$ of the total area of the country, fig. 2. It is located in the northern part of Iraq within the area bordered by Tigris and Euphrates Rivers. Most of the area $(80 \%)$ is within the Ninevah Governorate with minor parts within the Al-Anbar and Salah Ad-Din Governorates. The area has very sparse population due to the lack of suitable water resources. Many large valleys drain the area and the water from most of them is discharged in the Euphrates River and Tharthar Lake, fig. 2. The mean annual temperature in the Al-Jazira area is (30-33) ${ }^{\circ} \mathrm{C}$, and the average annual amount of evaporation 3000-3200 mm [25]. Rainfall occurs during winter (December to February) in this area, increasing northwards from $150 \mathrm{~mm}$ in the south to $200-300 \mathrm{~mm}$ in the center and further, gradually, to $400 \mathrm{~mm}$ in the north. The potential of evaporation in the area is several times higher than the average rainfall [25].

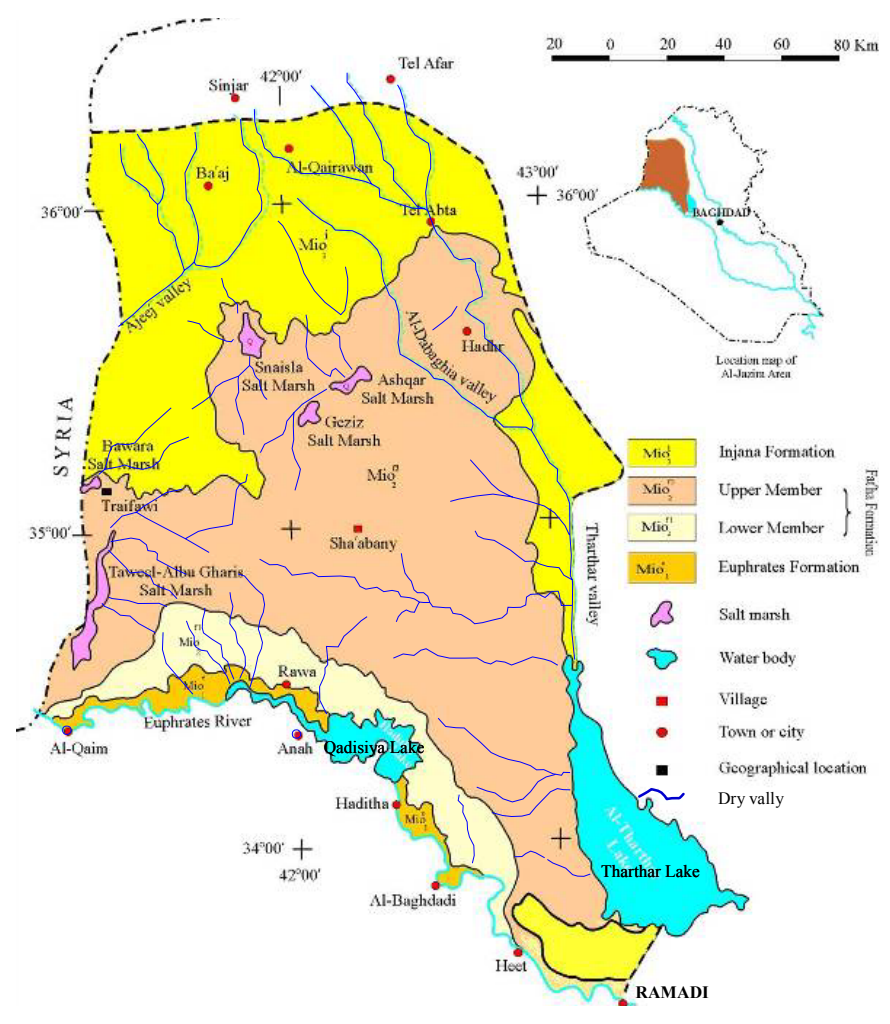

Figure 2: $\quad$ Geological map of Al-Jazira Area, modified from Sissakian [28]. 


\subsubsection{Topography}

The topographic gradient of Al-Jazira Area decreases from north to south. The highest point (400 m AMSL) is located south of the Sinjar Mountain and the lowest point (50 m AMSL) is south of Tharthar Lake. The area is characterized by flat terrain and rising towards north. Two denudational plains can be recognized within the area and they are intersected by many valleys. The length of the valleys may reach several kilometres and their cross sectional area is usually wide. The southern plain is characterized by isolated hills that can be a few meters high, occasionally up to $30 \mathrm{~m}$. Some of them are believed to be ancient settlements [25].

Other features are depressions resulting from erosion (salt marshes), solution (karsts) or swelling ("Blister voids"). They have different shapes and some of them are exceptionally large (Tharthar Lake) while others have an extension of only a few kilometres [25]. Due to the extensive evaporation, the area has undergone solution and karstification [26]. Accordingly, numerous sinkholes of varying dimensions have developed. Some of them may be flooded in rainy seasons and eventually become ephemeral lakes. They can later dry up and become salty pans. The area is also dominated by gypcrete soil and salt playas. The soil varies in thickness from $0.3 \mathrm{~m}$ in the elevated parts to $8 \mathrm{~m}$ in depressed areas. The gypsum content is high, ranging from 30 to $80 \%$. Also, there are three major playas, i.e. the Sunaisla playa created by topographic depression, and the Bowara playa at the Iraqi-Syrian border, and the Tawila playa located at the contact between the Fatha and Injana formations, fig. 2 [27].

\subsubsection{Formation}

The oldest exposed formation in the area is of Late Oligocene and Miocene age, fig. 2 [26, 29]. The Anah Formation (Late Oligocene) is the oldest exposed one. It is composed of limestone, creamy in colour, fine crystalline, massive, very hard, coralline and fossiliferous [30]. Its exposure is restricted to a very narrow strip along the left bank of the Euphrates River south of the Al-Jazira area. The Euphrates Formation (Early Miocene) is exposed in a narrow strip along the Euphrates River and Haitha lakes. It consists of basal conglomerate, followed by dolostone and dolomitic limestone, white fossiliferous limestone alternating with pseudoolitic chalky like limestone in its lower parts, and white fossiliferous limestone, in turn alternating with pseudoolitic chalky limestone in its middle part, while the upper part is composed of alternating grey limestone and green marl [30].

Fatha (Lower Fars) Formation (Middle Miocene) is exposed mainly in the southern and middle parts of the area, e.g. in the southern part of Al-Jazira Area along the northern side of the Euphrates Valley in the form of narrow cliffs. The lower member of the formation is of cyclic nature, each cycle starting with green marl, limestone and ending with gypsum facies [31-35]. The upper part of the formation is exposed in the middle part of Al-Jazira Area and occupies a wide area there. It is of cyclic nature with 7 cycles recognized [33]. The composition is similar to that in the lower part, where red claystone and sandstone appear [29]. 
The Injana (Upper Fars) Formation (Late Miocene) is exposed mainly in the northern parts of the area, together with Quaternary sediments [28]. They vary in thickness from a few centimeters to $10 \mathrm{~m}$ and represent sediments of alluvial, evaporation, slope and residual types [29]. In the Al-Jazira area the formation consists predominantly of red, brown and grey claystone, siltstone and sandstone, overlying the uppermost gypsum bed of the Fatha Formation. Generally, the formation comprises of repeated cycles of sandstone, siltstone and claystone. In the lower part, thin horizons of fossiliferous and oolitic limestone occur locally [29].

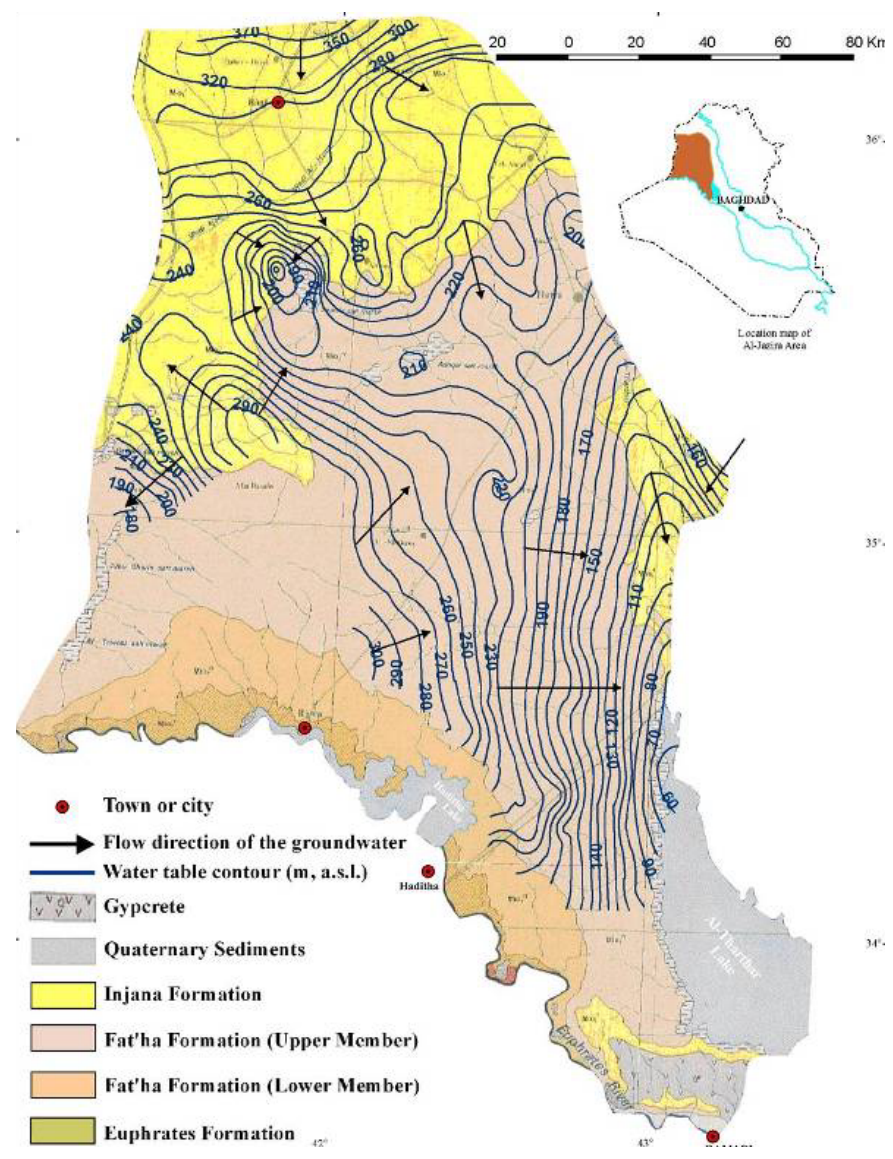

Figure 3: Hydrogeological and geological map of Al-Jazira Area with groundwater level (AMSL) and direction of flow, after Sissakian [27].

\subsubsection{General hydrology}

The drainage of the Al-Jazira area is directed to marshes, swamps and sabkhas, and takes place along sloping large-scale structures. The main water recharge is 
by direct infiltration from the central wadies to shallow aquifers. Flowing groundwater discharges along the Tharthar Lake and sabkhas. The main waterbearing formations are the Fatha and Injana deposits and Quaternary sediments [36]. The trend of groundwater flow is generally from north to south, southeast and southwest, fig. 3. There are minor deviations from this pattern due to the impact of local geological and topographical processes. The salinity of the groundwater ranges from about 300 to $7000 \mathrm{mg} / \mathrm{l}$. It is high in the discharge areas in the south and logically decreases towards north, i.e. in the direction to the recharge area. The water quality is mainly sulphatic with chloride and bicarbonate. The groundwater depth varies from 3 to more than $60 \mathrm{~m}$ below the surface ground level [36].

\subsubsection{Tectonic layout}

Respecting tectonics, most of the Al-Jazira province lies within a stable shelf area [26]. According to Alsinawi [37] large parts of the area is believed to be in a seismically undamaged zone and the rest of it in a zone of minor damage. Historical studies of earthquake events in Iraq indicate that large parts of the AlJazira area did not experience any impact of seismic events in the past and that the remaining small areas were affected by only few minor earthquakes [38]. The Al-Jazira desert is stable, implying stability also of the disposal facility. The deeply located groundwater level is another beneficial property of this desert area especially for constructing repositories in the middle and southern parts. However, depression areas containing free water, salty marshes and karst terrains occur and should be avoided.

The Al-Jazira area has a number of isolated hills representing suitable construction conditions. Most of Al-Jazira desert is of low land type that is not suitable for cultivation because of its high gypsum content and low precipitation. The central and southern parts are also candidates since the tight shallow soil here will minimize rainwater infiltration. Since the ancient Hatra city (Hadhr) is one of the most important archaeological features in the area, due respect to it has to be paid in the siting process, fig. 2 .

\section{Conclusions}

The formulation of siting criteria is the first vital step toward the resolution of the problems with safe disposal of HW in Iraq, especially of DU-contaminated soil and solids. It is the authors' opinion that the Al-Jazira desert represents a number one candidate for location of one or several landfills of such hazardous waste, primarily because of the suitable topography, climatic conditions and seismic stability, and also of the low population intensity, and of the availability of raw materials. The western and southern deserts can also be utilized for hosting a HW repository because they offer similar good prerequisites as AlJazira desert. 


\section{References}

[1] Bleise A., Danesi P.R. and Burkart W., Properties, use and health effects of depleted uranium (DU): A general overview. Journal of Environmental Radioactivity, 64 (2003), pp. 93-112, 2003.

[2] Åkerblom, G., Depleted uranium - Experience of the United Nations environmental programme missions. 8th International Symposium on the Natural Radiation Environment, NRE VIII, AIP conference proceedings, pp. 69-77, 2008.

[3] Radiological conditions in selected areas of southern Iraq with residues of depleted uraniu; International Atomic Energy Agency, radiological assessment reports series. Online, http://www-pub.iaea.org/MTCD/ publications/PDF/Pub1434_web.pdf (accessed 13 Feb 2012).

[4] Report on the Environmental fact in 2007, Ministry of Environment of Iraq, (published in Arabic), Online, http://www.moen.gov.iq/waq3.html (accessed 13 Feb 2012).

[5] Abbas, M., Al-Atia, M., Bushra A., Helou T., Al-Mubarak M., Danneels J., Cochran R. J., Sorenson K. and Coates R. Decommissioning of the Iraq Former Nuclear Complex. Proceedings of the 11th International Conference on Environmental Remediation and Radioactive Waste Management, Bruges, Belgium, ICEM07-7280, 2007.

[6] Bertell, R., Depleted uranium: All the questions about DU and Gulf War syndrome are not yet answered. International journal of health services, 36(3), pp. 503-520, 2006.

[7] Busby C., Hamdan M. and Ariabi E. Cancer, Infant Mortality and Birth Sex-Ratio in Fallujah, Iraq 2005-2009. International Journal of Environmental Research and Public Health. 7(7), pp. 2828-2837, 2010.

[8] Introduction to hazardous waste identification (40 CFR part 261), solid waste and emergency response $(5305 \mathrm{~W})$; United States environmental protection agency, EPA 530-K-05-012 online. http://www.epa.gov/ wastes/inforesources/pubs/training/hwid05.pdf

[9] Chien, C. C., Barrier systems for environmental contaminant containment and treatment, CRC Press, Hoboken, 2006.

[10] Pusch, R., Waste disposal in rock, Elsevier, Amsterdam, 1994.

[11] Long-term institutional management of U.S. Department of Energy legacy waste sites [Electronic resource], National Academy Press, Washington, D.C., 2000.

[12] Daniel, D.E. (ed.), Geotechnical practice for waste disposal, Chapman and Hall, 1993.

[13] La Manche storage center (CSM), Nuclear France: materials and sites, By Mary Byrd Davis, online, http://www.francenuc.org/en_sites/ lnorm csm e.htm. (accessed $13 \mathrm{Feb} 2012$ ).

[14] Soulaines-centre de stockage de l' Aube (CSA), Nuclear France: materials and sites, By Mary Byrd Davis, online, http://www.francenuc.org/ en_sites/champ_csa_e.htm. (accessed $13 \mathrm{Feb} 2012$ ). 
[15] Low and intermediate level waste management in Spain. Online, newmdb.iaea.org/GetLibraryFile.aspx?RRoomID=423. (accessed 13 Feb 2012).

[16] Leon, J. L. -L., Current Status of the Radioactive Waste Management Programme in Spain. Proceedings of the $11^{\text {th }}$ international conference on environmental remediation and radioactive waste management, ICEM2007. Bruges, Belgium pp. 47-59, 2007.

[17] Experience of developing and siting a near surface repository in Lithuania, International atomic energy agency, online. http://www.iaea.org/ OurWork/ST/NE/NEFW/CEG/documents/ws022009/3.\%20Near\%20Surfa ce $\% 20$ Repositories $/ 3.1 \% 20$ Development $\% 20$ of $\% 20$ NSR $\% 20 \mathrm{in} \% 20$ Lituani a\%20Engl.pdf. (accessed 13 Feb 2012).

[18] International peer review of the program for evaluating sites for near surface disposal of radioactive waste in Lithuania, report of the IAEA international review team. Online. http://www-pub.iaea.org/ MTCD/publications/PDF/IAEA-LIT_web.pdf. (accessed 13 Feb 2012).

[19] http://www.edram.info/en/edram-home/picturegallery/enresa/index.php?tx_gooffotoboek_pi $\% 5 \mathrm{Bfid} \% 5 \mathrm{D}=2 \& \mathrm{cHash}=\mathrm{bc} 3$ a49dd059ce4e21acea488d0aa1026

[20] The national program of France in past and future low-level waste disposal: 30 years of progress. Online. http://www.wmsym.org/ archives $/ 1998 / \mathrm{html} / \mathrm{sess} 01 / 01-01 / 01-01 . h t m$ (accessed 13 Feb 2012).

[21] Oweis, I.S. and Khera, R.P., Geotechnology of waste management, $\left(2^{\text {nd }}\right.$ ed.), PWS Publishing Co.: Boston, Mass., 1998.

[22] Qian, X., Koerner, R.M. and Gray, D.H., Geotechnical aspects of landfill design and construction, Upper Saddle River, N.J.: Prentice Hall, 2002.

[23] Allen, A. R., Dillon, A. and O'Brien, M., Approaches to landfill site selection in Ireland. Engineering geology and the environment. Proc. symposium, Athens, Marinos, Koukis, Tsiambaos and Stournaras (eds), pp. 1569-1574, 1997.

[24] Bagchi, Amalendu, Design, construction and monitoring of landfills, ( $2^{\text {nd }}$ ed.) John Wiley \& Sons: New York, 1994.

[25] Ma'ala, K., Geomorphology of Al-Jazira Area, Iraqi Bull. Geol. Min., Special Issue, 3, pp. 5-31, 2009.

[26] Fouad, S. and Nasir, W., Tectonic and Structural Evolution of Al-Jazira Area, Iraqi Bull. Geol. Min., Special Issue, 3, pp. 33-48, 2009.

[27] Aqrawi, A. M., Domas, J. and Jassim, S. Z., Quaternary deposits (Chapter 15). Geology of Iraq, eds. Jassim, S. and Goff, J., Doblin, Prague and Moravian Museum, pp. 185-198, 2006.

[28] Sissakian, V.K., Geological Map of Iraq, scale 1: $1000000,3^{\text {rd }}$ ed. GEOSURV, Baghdad, Iraq, 2000.

[29] Ma'ala, K. and Al-Kubaysi, K., Stratigraphy of Al-Jazira Area, Iraqi Bull. Geol. Min., Special Issue, 3, pp. 49-70, 2009.

[30] Al-Mubarak, M.A., Final geological report of upper Euphrates Valley, GEOSURV, internal report No. 677, 1971. 
[31] Ibrahim, Sh. B. and Sissakian, V.K., Report on the Rawa - Baiji - Tikrit Al-Baghdadi Area. GEOSURV, internal report No. 675, 1975.

[32] Al-Jumaily, R.M., Report on the regional geological mapping of Al-Jazira (Bawara - Ash, Sha abani Area). GEOSURV, internal report No. 771, 1976.

[33] Ma'ala, K.A., Report on the Regional Geological Mapping of Hadhr Area. GEOSURV, internal report No. 742, 1976.

[34] Sissakian, V.K. and Hafidh, Sh. Q., The Geology of Haditha Quadrangle, scale 1: 250 000. GEOSURV, Baghdad, Iraq, 1993.

[35] Sissakian, V.K. and Hafidh, Sh. Q., The Geology of Wadi Al-Miyah and Albu Kamal Quadrangles, scale 1: 250 000. GEOSURV, Baghdad, Iraq, 1994.

[36] Al-Jiburi, H. and Al-Basrawi, N., 2009, Hydrogeology of Al-Jazira Area, Iraqi Bull. Geol. Min., Special Issue, 3, pp. 71-84, 2009.

[37] Alsinawi, S., Seismicity (Chapter 7). Geology of Iraq, ed. Jassim, S. and Goff, J., Doblin, Prague and Moravian Museum, pp. 84-90, 2006.

[38] Alsinawi, S. and Al Qasrani, Z.Q., Earthquake hazards consideration for Iraq. Proc. Intern. Conf. of Earthquake Eng. and Seismology, Tehran, Iran. 2003. 